\title{
A PRODUÇÃO DO ESPAÇO PRISIONAL PELO ESTADO: UM ESTUDO DO COMPLEXO PENITENCIÁRIO NO KM 8 DA BR-174 -
} MANAUS-AM

\section{RESUMO}

BELÉM, Sansão da Silva ${ }^{1}$

BELÉM, Sansão da Silva. A produção do espaço Prisional pelo estado: um estudo do complexo penitenciário no km 8 da br-174 - Manaus-AM. Revista Científica Multidisciplinar Núcleo do Conhecimento. Ano 04, Ed. 05, Vol. 05, pp. 136-158 Maio de 2019. ISSN: 2448-0959

\section{RESUMO}

Historicamente o sistema prisional do Estado do Amazonas traz consigo a problemática da superlotação das cadeias, sendo que o problema persiste desde o século XX aos dias atuais. A primeira cadeia com estrutura de penitenciaria remonta aos anos de 1924 com a construção da Cadeia Pública Desembargador Raimundo Vidal Pessoa, dessa forma há um déficit constante de vagas disponível e excesso de internos, nesse sentido o Estado passou a construir vários presídios sendo que direcionou tais presídios para a BR-174 km 8, uma forma de afastar os presídios da área central da cidade. O espaço urbano capitalista está cada vez mais articulado, em busca de fazer e refazer a cidade, neste sentido esta pesquisa, realizada no $\mathrm{Km} 8 \mathrm{da}$ BR-174 Manaus-Boa vista, teve como objetivo geral analisar a produção do espaço urbano promovido a partir do Estado, no entorno do complexo de presídios do $\mathrm{Km} 8$ da BR-174 Manaus-Boa vista e, como objetivos específicos, descrever de que forma é feita esta produção do espaço, identificando os agentes sociais formadores da produção do espaço no Km 8 BR-174 e discutindo as possíveis consequências dessa produção de espaço, considerando o entorno da entrada do ramal de acesso do

\footnotetext{
${ }^{1}$ Licenciado em Geografia, pela Universidade do Estado do Amazonas - UEA; Escola Normal Superior.
} 
complexo penitenciário. Para atingir tais objetivos utilizou-se o método hipotético dedutivo, no qual ao longo da pesquisa poderá ser confirmado ou não as hipóteses, bem como suas deduções. Tendo as seguintes questões norteadoras. Pode ocorrer uma ocupação irregular nesta área? Pode ocorrer a produção de comércio e feiras? Diante da produção do espaço pelo Estado, bem como dos outros agentes sociais presentes, pode-se fazer e refazer um novo bairro? O embasamento teórico utilizase, dentre outros autores, da leitura de Roberto Lobato Corrêa e Milton Santos, os quais definem e discutem os agentes produtores do espaço urbano, bem como a ação e os interesses de cada um deles, os quais apresentam as contradições da própria sociedade. A partir dos questionamentos postos e observando o processo contínuo da apropriação, da ocupação, e do consumo do espaço é que se realiza toda a discussão. Como resultado da pesquisa foram identificados sete presídios construídos pelo Estado no ramal, bem como atividades de obras de reforma e nova construção; uma população carcerária de 4.121 somente nos presídios do ramal, atividades comerciais e serviços de vários segmentos: comércio de gênero alimentício na entrada do ramal, membros de igreja, mototaxis, kombis-lotação. Sobre a situação fundiária identificou-se, através do INCRA, a propriedade dos lotes, neste sentido os resultados da pesquisa foram além das expectativas iniciais, porque elementos humanos e físicos se interagem e estão relacionados direto na produção, no consumo, na apropriação, organização e modificação do espaço. Por fim, foi possível perceber a ocorrência de uma ocupação irregular, por parte dos comerciantes locais na área, com perspectiva de fundar uma associação de barraqueiros, por consequência poderá haver uma ocupação para residência, ficando pela própria dinâmica da produção e consumo do espaço a emergência de um novo bairro nas proximidades do ramal.

Palavras-Chave: Complexo Penitenciário, Estado, Espaço Urbano.

\section{INTRODUÇÃO}

O sistema prisional do Estado do Amazonas remonta ao início do sec. $\mathrm{XX}$, mais precisamente em 1904 durante a gestão de Antônio Constantino Nery, foi possível iniciar as obras de construção da Casa de Detenção de Manaus que se tornou em 1924 Cadeia Pública Desembargador Raimundo Vidal Pessoa (CPDRVP), que na 
ocasião era o único lugar do Estado do Amazonas no qual segregavam as vítimas do sistema capitalista das classes mais desassistidas do poder público da época (PRADO, 2015, p. 30-31).

$\mathrm{Na}$ Capital com o aumento populacional e consequentemente as mazelas oriundas da sociedade, e os problemas sociais, houve lotação do presidio, e de certa forma uma tensão para aliviar a superlotação do presidio com necessidade de construir mais prisões.

Nesta perspectiva o Governo do Amazonas começa a construção de novos presídios, com o propósito de atender a Lei do Código Penal que aduz:

CP - Decreto Lei no 2.848 de 07 de Dezembro de 1940

Art. 33 - A pena de reclusão deve ser cumprida em regime fechado, semiaberto ou aberto. A de detenção, em regime semi-aberto, ou aberto, salvo necessidade de transferência a regime fechado. (Redação dada pela Lei no 7.209 , de 11.7.1984)

$\S 1^{\circ}$ - Considera-se: (Redação dada pela Lei $\mathrm{n}$ 7.209, de 11.7.1984)

a) regime fechado a execução da pena em estabelecimento de segurança máxima ou média;

b) regime semi-aberto a execução da pena em colônia agrícola, industrial ou estabelecimento similar;

c) regime aberto a execução da pena em casa de albergado ou estabelecimento adequado.

Em virtude da lei n 2.848 de 1940, 42 anos após a criação da lei foi criado em 1982 a Colônia agrícola Anísio Jobim (CAIAJ), a primeira estrutura construída neste ramal da BR-174 Km 8, e em seguida o Estado surge como consumidor e agente produtor do espaço direcionando a maioria dos presídios da capital na construção de mais seis unidades prisionais neste mesmo espaço. 
Diante da produção do espaço pelo Estado através da construção de vários presídios no Km 8 da BR-174 sentidos Manaus- AM/ Boa vista/RR, está havendo uma aglomeração de pessoas tais quais: visitantes dos internos, os moto taxistas, os motoristas de Kombi lotação, vendedores ambulantes, membros de igrejas, os comerciantes de lanche e refeição, os comerciantes de comercio de estivas. Logo o circuito inferior é aquele constituído fundamentalmente por formas de fabricação nãocapital forte pelos serviços que não acompanham a modernidade e dessa forma são fornecidos a varejo e pelo comércio não- moderno e de pequena dimensão (SANTOS, 2004 , p. 40). Atividades estas muitas vezes enraizadas no próprio lugar, que visam suprir as demandas de uma população local e mais pobre, configurando assim uma divisão do trabalho que é operada pelo próprio lugar. Todas essas pessoas são contidas na entrada deste ramal pela Força Nacional de Segurança Pública (FNSP), que só adentra a parte dos presídios mediante ser visitante, ou trabalhador de algum presídio ali estabelecido, ou prestadores de serviços do Estado as empresas terceirizadas, ou funcionários da Secretaria de Estado de Administração Penitenciária (SEAP).

O espaço urbano capitalista está cada vez mais articulado, em busca de fazer e refazer a cidade, neste sentido esta pesquisa foi realizada no Km 8 da BR-174 Manaus-Boa Vista, teve como tema: A Produção do Espaço pelo Estado, A Partir do Complexo Penitenciário na BR- 174 Km 8 - Manaus-AM.

Inquestionavelmente a situação problema que está ocorrendo neste lugar, é que, por consequência da produção do espaço pelo Estado através da construção de vários presídios no Km 8 da BR-174 sentidos Manaus- AM/ Boa vista/RR, está havendo uma concentração de pessoas, visto que as mesmas são contidas na entrada deste ramal pela Força Nacional, que só adentra aos presídios mediante ser visitante, ou trabalhador de alguns presídios ali construído, ou prestadores de serviços do Estado e funcionário da SEAP.

A Força Nacional de Segurança Pública é um órgão de cooperação federativa cuja função é preservar a ordem pública, a segurança das pessoas e do patrimônio. É uma tropa de "pronta-resposta", segundo o Ministério da Justiça. Atua em situações de 
emergência e calamidade pública, além de operações ambientais. Trata-se de um órgão que trabalha em conjunto com instituições de segurança pública de qualquer região do país, a fim de resolver os mais diversos tipos de conflito, entretanto a presença desta força policial na entrada do ramal de acesso se deu em virtude da rebelião ocorrida em 01/01/2017, quando 56 presos morreram na rebelião do Complexo Penitenciário Anísio Jobim (COMPAJ).

Muitos dos visitantes acampam neste lugar para que no dia seguinte, os mesmos sejam logo atendidos para adentrar nas unidades prisionais no qual o seu familiar está sob a custódia do Estado e ter o seu direito de visita assegurado para manutenção do convívio familiar.

Atualmente há uma população carcerária de 4.036, distribuídas nesses sete presídios, conforme fonte da SEAP, o que justifica a grande movimentação por parte dos parentes dos internos no entorno do espaço, por consequência trouxe o comércio, membros de igreja, moto taxi, Kombi lotação à beira da BR-174 Km 8 .

De certa forma o espaço está sendo modificado pelo homem, percebe-se um palco de grandes acontecimentos sociais, assim sendo Sposito (1994, p.18-19) assinala que:

[...] Essas medidas são possíveis porque o poder público atua sobre o uso do solo urbano das seguintes maneiras:

a) utilizando seu poder de regular as atividades da iniciativa privada;

b) desapropriando imóveis, através de decisões jurídicas, que sejam de interesse ou de utilidade pública;

c) utilizando terrenos urbanos para seus próprios empreendimentos (prédios para instituições públicas, praças parques, etc.);

d) estimulando ou desestimulando os arranjos determinados pela iniciativa privada. 
Como podemos observar a atuação do poder público tanto na esfera federal, quanto na esfera estadual na área pesquisada é bastante atuante, dinâmica e coesa com os demais agentes produtores do espaço, e é nesta perspectiva que objetivou a analisar esses processos entre o homem e o meio ambiente.

Desse modo as questões norteadoras foram buscar compreender: Eventualmente pode ocorrer uma ocupação irregular nesta área? Ou se pode ocorrer a produção de comercio e feiras? E além disso diante da produção do espaço pelo Estado e outros agentes sociais, podem fazer e refazer um novo bairro?

Por consequência, ao observar como o Estado, sendo um agente social produtor do espaço, ele está à frente dessas mudanças espaciais que estão ocorrendo na área estudada, foi usado pesquisa quantitativa e qualitativa, com método hipotético dedutivo, por isso que para fundamentar este método segundo Sposito (2004, p.2930) aponta que:

Como já anotamos em matéria anterior (Sposito, 1999), o método hipotético-dedutivo, citando Japiassu \& Marcondes (1990), é aquele "através do qual se constrói uma teoria que formula hipóteses a partir das quais os resultados obtidos podem ser deduzidos, e com base nas quais se podem fazer previsões que, por sua vez, podem ser confirmadas ou refutadas". Entretanto, [...].

É nessa perspectiva de análise do método hipotético dedutivo, que foi feita essa pesquisa, porquanto as previsões do que pode ocorrer no espaço urbano poderá ou não ocorrer uma ocupação irregular dos grupos sociais excluídos, ou a apropriação dos espaços a partir de comércios e feiras, e, por conseguinte a formação de um novo bairro.

O objetivo geral deste trabalho foi de analisar a produção do espaço promovido pelo Estado, no entorno do complexo de presídios no Km 8 da BR-174 Manaus-Boa Vista. Quanto aos objetivos específicos foi de descrever de que forma está sendo feita esta produção; identificar os agentes sociais formadores e consumidores do espaço no Km 
8 da BR-174; e discutir as possíveis consequências desta produção do espaço, no entorno da entrada de acesso do complexo penitenciário.

Para entender como agem os agentes sociais e consumidores do espaço, suas ações, suas estratégias no processo de fazer e refazer a cidade, este trabalho tem como contribuição de colocar nas questões urbanas a produção do espaço pelo Estado através do Complexo Penitenciário do Amazonas e ter uma fonte de informação teórica voltada a esta temática, que por se tratar de um setor tão problemático dentro do âmbito Nacional, o Estado por sua vez contribui custodiando essas pessoas, passando a ser o principal agente produtor do espaço, na construção de sete presídios nesta área que foi pesquisada.

Para alcançar os objetivos nesta pesquisa, utilizei de pesquisas bibliográficas e documentais em busca de informação da área, realizando entrevista com órgãos públicos tanto federal como estadual, fazendo a escrita da pesquisa conforme o andamento da mesma, esclarecendo dúvidas e orientações com o professor, coletando informações locais com as pessoas que já estabeleceram pequenos comércios e obtendo imagem fotográficas do local, aplicando questionário aos vários segmentos na área de estudo para sistematizar esses dados e interpreta-los.

\section{METODOLOGIA E PROCEDIMENTOS}

Este artigo foi realizado no período de janeiro de 2017 até novembro de 2018, e se fundamenta em um estudo de caso, porquanto se baseia em uma pesquisa descritiva de caráter qualitativo, sendo que os fatos são observados, registrados, analisados, classificados, sem nenhuma interferência do pesquisador.

Assim sendo, a pesquisa dividiu-se em cinco etapas (figura 1), e adotados os seguintes procedimentos metodológicos: No primeiro momento foi realizado um levantamento bibliográfico, no qual os principais materiais bibliográficos foi utilizado no decorrer do trabalho, adquirindo embasamento teórico e cientifico através de livros, artigos, dissertações, teses, legislações pertinentes, e entre outros. Dessa forma foi possível organizar as ideias que embasaram as teorias de tal análise. 
$\mathrm{Na}$ segunda etapa, foi efetuado um levantamento de imagens através de sensoriamento remoto de satélite, a partir do Google Earth que é um programa de computador no qual serviu para delimitar a área de pesquisa, e em seguida levantamento de informações em campo através do uso do GPS que identificou pelas coordenadas geográficas o local da área.

A terceira etapa foi realizado levantamento de campo com anotações e observações relevantes, e fazendo uso de registro fotográfico com a câmera do celular, e registro das coordenadas geográficas para identificar com exatidão a área da pesquisa,

$\mathrm{Na}$ quarta etapa foi elaborado a classificação dos dados colhido em campo, tendo como classificação 1 os dados obtidos em campo através do setor de estatística da Secretaria de Administração Penitenciaria (SEAP) coletando o quantitativo da população carcerária e o número de visitantes que circulam no local estudado, consequentemente a classificação 2 ficou por conta dos dados obtidos através da abordagem da aplicação do questionário (problemática e satisfação) fechado e de múltipla escolha, durante os dias de visita 19,20 e 21 de outubro de 2018. Sendo entrevistados 50 visitantes, 10 comerciantes, 4 moto taxis, 4 servidor da SEAP, e voluntários da Igreja Universal do Reino de Deus, que utilizam do espaço do entorno do ramal.

Finalmente a quinta etapa foi executado uma sistematização, análise e interpretação dos dados obtidos no qual as informações adquiridas foram elaboradas em planilhas de Excel, com a finalidade de gerar gráficos, tabelas dando suporte para os resultados e discussão.

Foi utilizado o método Hipotético-Dedutivo, já que hipótese é uma suposição que se faz a respeito do local a ser pesquisado, uma explicação provisória da produção do espaço (Sposito, 2004). E dedutivo, foi formulado uma serie de conclusão e planejamento para verificar se houve conclusões tiradas com as da realidade em campo sendo confirmada ou não. Dessa forma é de fundamental importância a referência feita por Spósito (2004, p.34) destaca que: 
O objeto prevalece sobre o sujeito, ou seja, o objeto estudado é posicionado a montante, influenciando o pesquisador e os seus conhecimentos, mesmo que a neutralidade científica seja um pressuposto básico. O real é descrito por meio de hipóteses e deduções.

Fazendo uso da abordagem no qual o homem utiliza a ciência para encontrar explicação de maneira precisa, os fenômenos e ocorrências que acontecem no espaço e sendo o homem um ser indissociável nessa dinâmica e suas transformações ao longo do tempo, visto que o método analisa o aspecto do fato histórico, e sua relação do ser com o espaço e este no contexto sócio econômico, cultural, e político, de uma maneira critica a fim de buscar resposta e indagações dos acontecimentos de como ocorreu ou porquê ocorreu.

Figura 1- Fluxograma das etapas

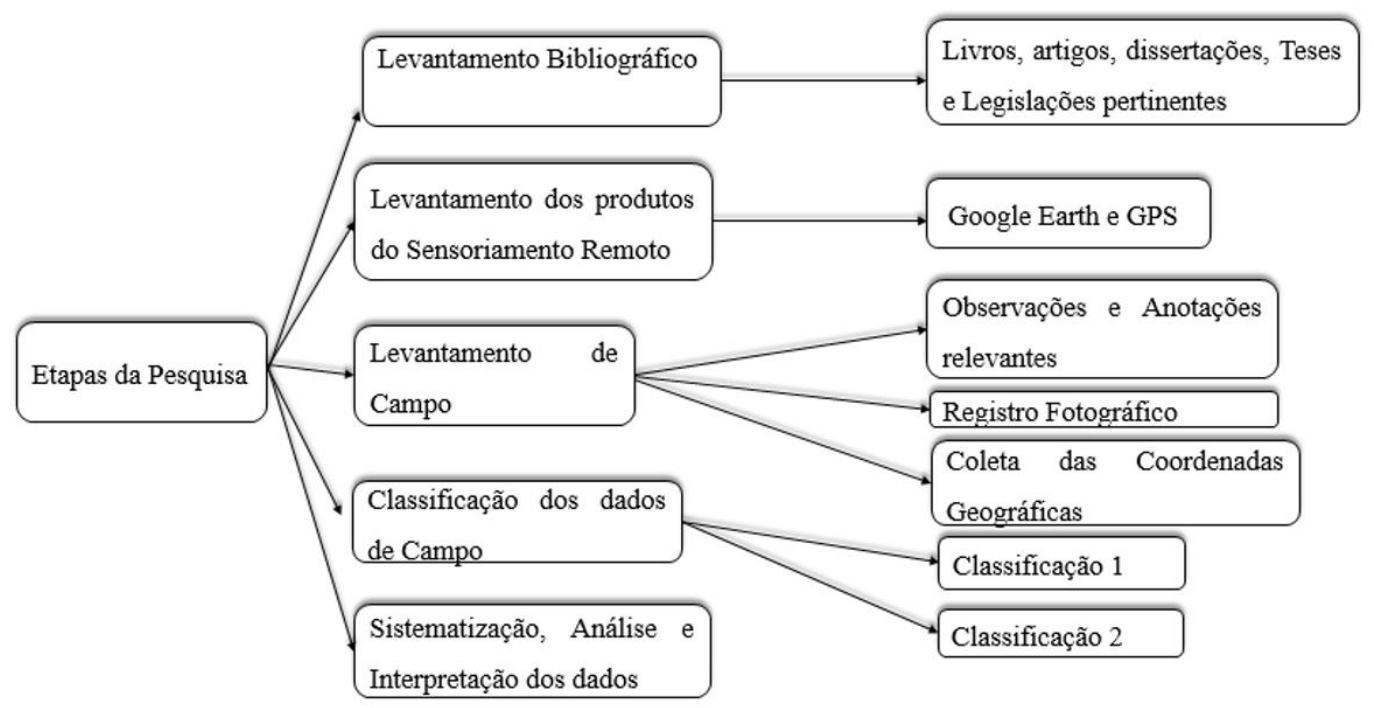

- Recorte Temático

A pesquisa realizada, faz parte da Geografia, no qual estuda o Urbano, as áreas urbanas e seus processos de produção do espaço urbano, as cidades, suas origens, crescimento, desenvolvimento e o entorno e tudo que acontece no espaço urbano. 
Por meio da geografia urbana conhecemos o comportamento da população, sua reprodução social e das comunidades em geral. Portanto o tema da pesquisa está encaixado dentro desta área de estudo, e tem como objetivo de identificar os principais agentes produtores do espaço no local da área pesquisada, assim como analisar a expansão de seu entorno.

\section{- Recorte Temporal}

A pesquisa levantada busca observar o ano de 2017 até novembro de 2018, mostrando como o Estado está articulando a produção do espaço nesta área.

\section{- Recorte espacial}

A área pesquisada encontra-se na região Norte do Brasil, no Estado do Amazonas, na capital Manaus, corresponde ao Km 8 da BR-174 - Manaus-Boa Vista.

Figura 2- Trajeto e área de pesquisa

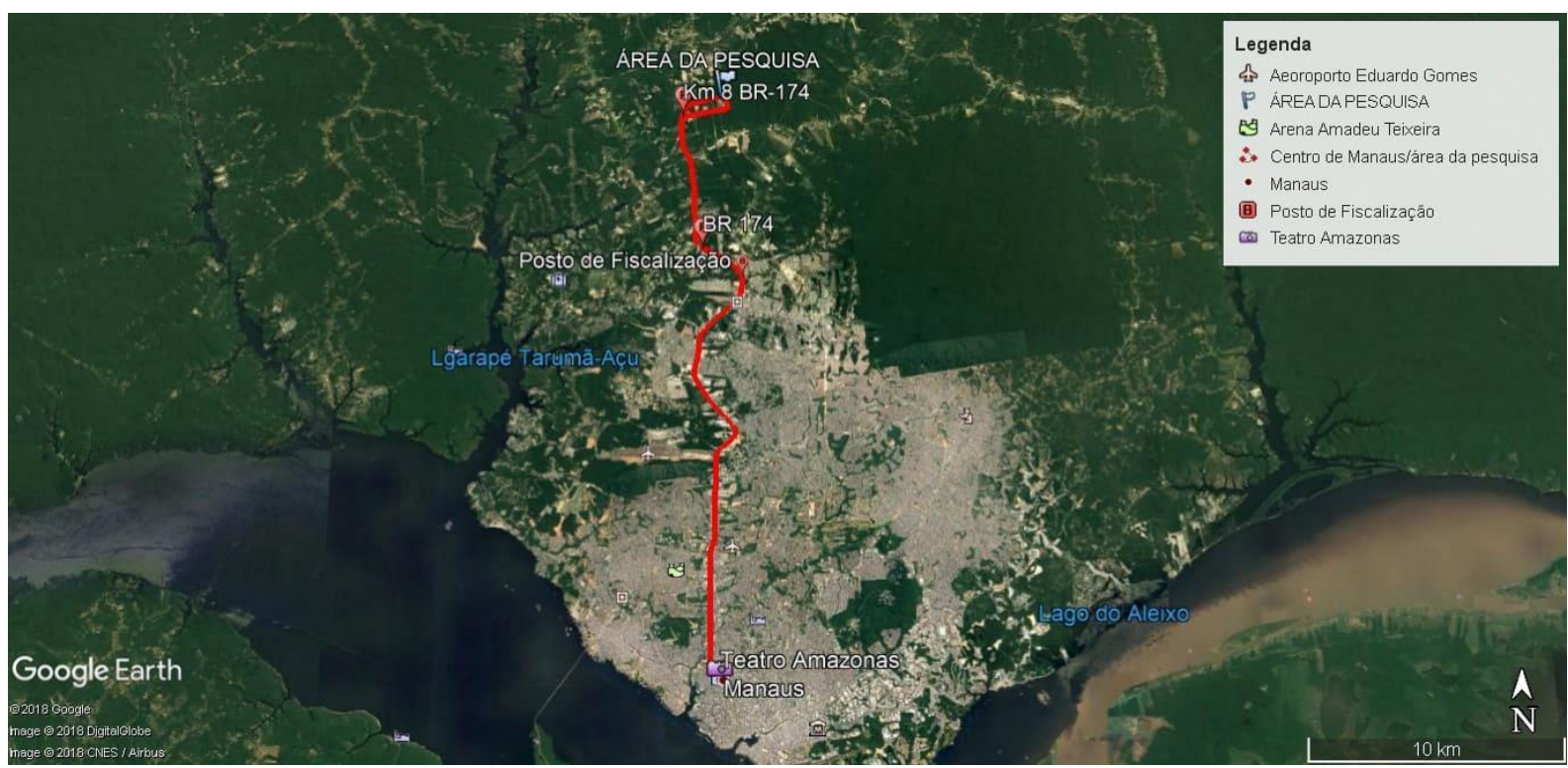

Fonte: Google Earth/ Adaptado por Sansão Belém, 2017.

A área de estudo está centrada na zona rural de Manaus e situa-se na zona norte da cidade, há 26,2 Km do centro da capital do Amazonas. Podemos observar a dinâmica de expansão da área urbana da cidade de Manaus a partir de dados de imagens de 
satélite, conforme imagem (figuras 2), essa expansão ruma ao setor norte e leste de Manaus.

A área do local da pesquisa está localizada entre o Paralelo $-2^{\circ} 54^{\prime} 17^{\prime \prime}$ Latitude Sul e Meridianos - $60^{\circ} 01^{\prime} 30^{\prime \prime}$ Longitude Oeste, e abrange uma área de floresta (figura 3), no qual aos poucos está sendo destruída pela ação antrópica, para a construção dos presídios.

Figura 3: Local da área de pesquisa

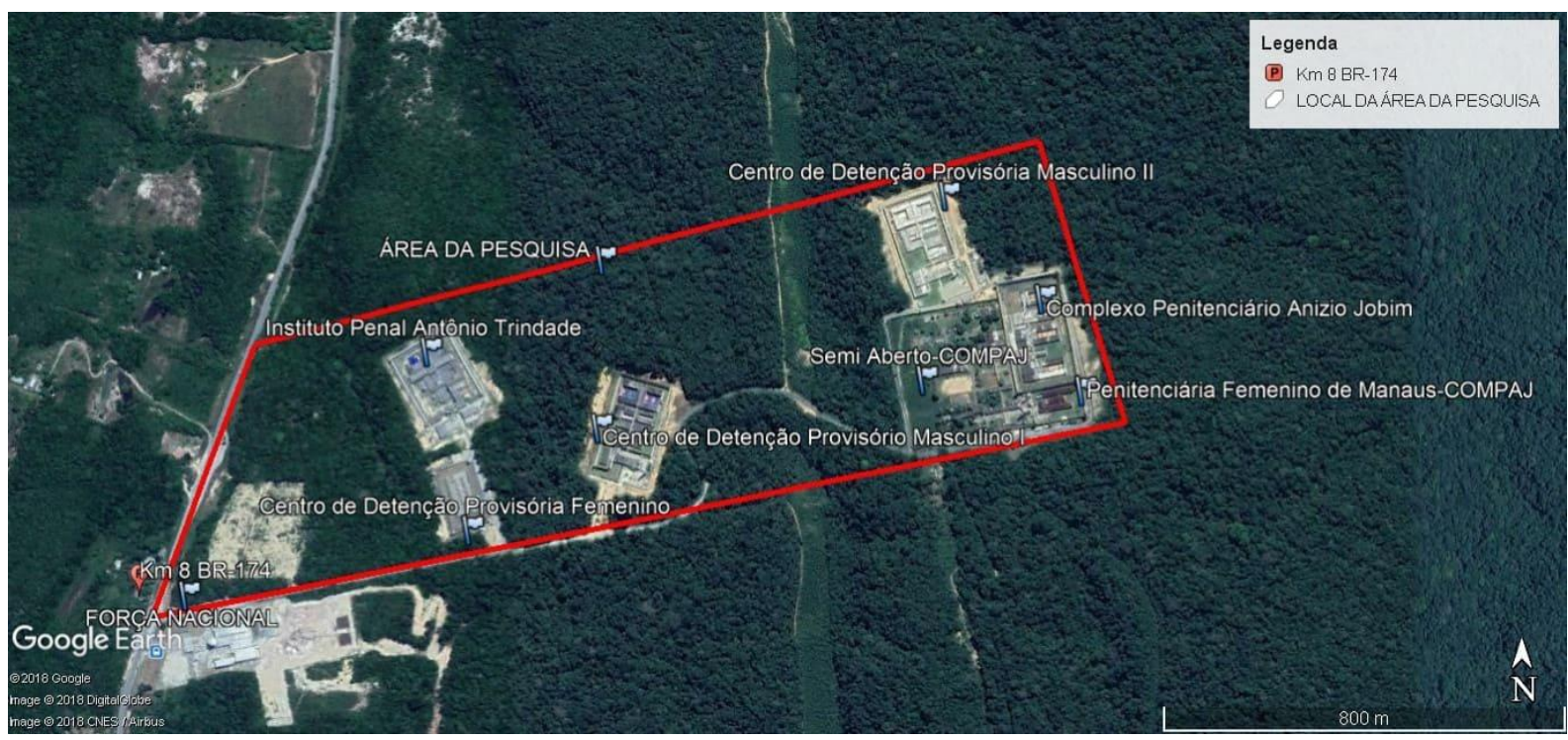

Fonte: Google Earth/Adaptado por Sansão Belém, 2017.

Como questão fundamental da problemática dessa situação citamos:

Pode acontecer uma ocupação irregular nesta área? Pode ocorrer a produção de comércio e feiras? Diante da produção do espaço pelo Estado os outros agentes sociais podem fazer e refazer um novo bairro?

As respostas a todos estes questionamentos serviram como base para comentar, ao longo deste trabalho com o tema: A produção do espaço pelo Estado, a partir do complexo penitenciário no Km 8 da BR-174 - Manaus-AM. 


\section{RESULTADOS E DISCUSSÕES}

Neste capítulo abordaremos um breve histórico do sistema prisional no Amazonas, bem como as primeiras construções para acomodações dos presos fazendo um relato temporal e espacial dos presídios, dando destaque para a construção da primeira cadeia pública do estado do amazonas Cadeia Pública Desembargador Raimundo Vidal Pessoa (CPDRVP), assim como um relato de como está sendo feito a apropriação do espaço pelo Estado a partir dos presídios no Km 8 da BR-174, ressaltando a influência da população encarcerada na formação sócio espacial, evidenciando a importância dos agentes formadores do espaço nesse processo.

A necessidade de ter um local onde pudesse alojar os ditos "infligidores" da lei, houve a obrigação urgente de uma estrutura para encarceramento dos presos, visto que a primeira cadeia pegou fogo junto com algumas casas vizinhas, isto no Lugar da Barra (Ferreira; Valois 2012). Explica Mário Ypiranga que a cadeia passou a funcionar onde hoje é o Palácio Rio Branco, porque até então o prédio não tinha a estrutura de uma cadeia. Nesse sentido obtém o registro bibliográfico no qual era o funcionamento improvisado de uma cadeia conforme Ferreira; Valois (2012, p.45) afirma que:

Apesar da dificuldade em se precisar o local exato de nossas primeiras cadeias, devido à precariedade das pequenas construções de então, o que nos dá a ideia de inúmeros casebres onde hoje pode estar localizado apenas um prédio, é certo que as cadeias estiveram sempre ao redor da praça D. Pedro II, naquele tempo Praça do Quartel, de onde a cidade de Manaus cresceu, fato que se confirmará com as informações dos primeiros e últimos anos do Império.

Como forma de tentar alojar os inúmeros presos desta época, foram utilizados os porões dos prédios ao redor da praça $\mathrm{D}$. Pedro II, como não tinha um prédio adequado com uma estrutura de penitenciária, então um dos porões utilizado foi deste prédio (figura 4). No ano de 1972, o Poder Legislativo se instalou no Palácio Rio Branco, no início da avenida Sete de Setembro, no Centro da Cidade. Nesse local, a Assembleia Legislativa, funcionou durante 34 anos até 2006. Atualmente o prédio funciona como 
centro de estudos de história política amazonense e espaço de animação cultural, no centro antigo, preservando a identidade do prédio com o parlamento estadual. $\mathrm{O}$ Centro Cultural Palácio Rio Branco foi revitalizado para visitação em 2010.

A dinâmica do crescimento de Manaus trouxe consigo o aumento da população, consequentemente os problemas sociais e seus conflitos de diversas formas, assim os delitos cometidos por essa sociedade ficaram mais crescentes, aumentando o contingente populacional desse presídio, que até aos anos de 1980 apenas existia uma casa de detenção que funcionava na Av: Sete de Setembro, com o nome de Cadeia Pública Desembargador Raimundo Vidal Pessoa, desativada no ano de 2017.

O Estado do Amazonas, possui um total de 18 unidades prisionais contando com as unidades do interior e da capital dos 61 municípios do interior existentes no Amazonas (IBGE,2010), apenas 7 possuem unidades prisionais, Itacoatiara com 2 unidades.

Das 10 unidades prisionais da Capital do Amazonas, 7 foram construídas no $\mathrm{Km} 8$ BR-174, (quadro 1), distante da área urbana da cidade, como forma de estratégia de afastar os presídios da área central da capital.

Quadro 1- Construção dos Presídios no Km 8 da BR-174

\begin{tabular}{|l|l|}
\hline Ano & Construção \\
\hline 1982 & CAIAJ- Colônia Agrícola Anísio Jobim \\
\hline $\mathbf{1 9 9 9}$ & COMPAJ- Complexo Penitenciário Anísio Jobim \\
\hline $\mathbf{2 0 0 0}$ & PFM- Penitenciária Feminina de Manaus \\
\hline $\mathbf{2 0 0 6}$ & IPAT- Instituto Penal Antônio Trindade \\
\hline $\mathbf{2 0 1 1}$ & CDPM I- Centro de Detenção Provisória de Manaus \\
\hline $\mathbf{2 0 1 4}$ & CDPF- Centro de Detenção Provisória Feminino \\
\hline $\mathbf{2 0 1 6}$ & CRT- Centro de Recebimento e Triagem \\
\hline 2017 & CDPM II- Centro de Detenção Provisória de Manaus II \\
\hline
\end{tabular}

Fonte: SEAP, 2018. 
Figura 4- Palácio Rio Branco

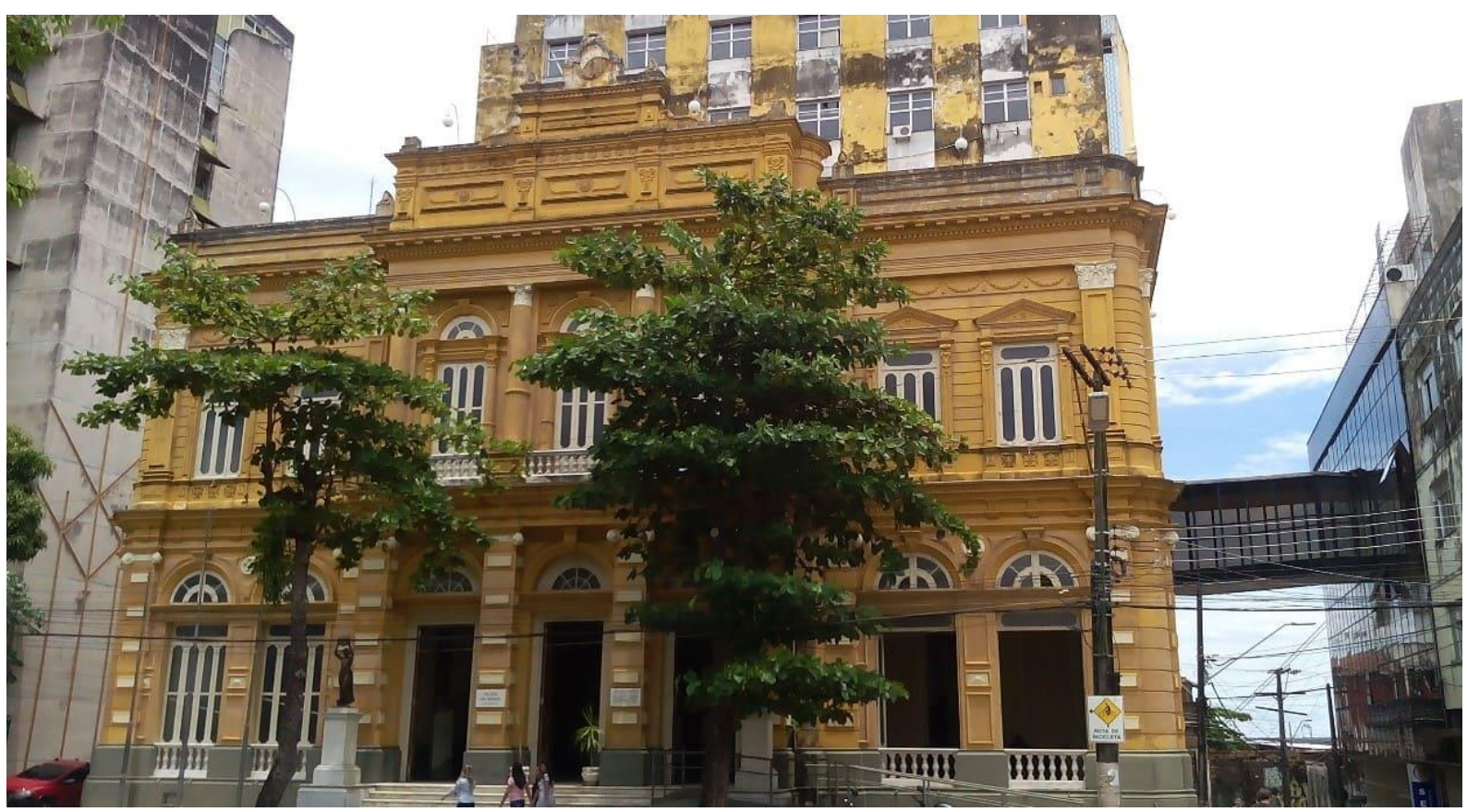

Foto: Sansão Belém, 2018.

Conforme podemos observar a produção do espaço de Manaus, à época, pouco era dado o valor necessário para a questão de alojar os aprisionados, uma vez que os casarões construídos muitos deles serviram de cadeia nos anos de 1852, segundo Ferreira e Valois (2012, p.59) ressaltam que:

Mas, Manaus, então Cidade da Barra, como capital da Província, não podia continuar com aquele antro, tendo sido uma das primeiras preocupações de Tenreiro Aranha conseguir um local em que se pudessem abrigar os presos e chamar de cadeia, esta que continuou na Praça do Quartel, pois era lá que estava o imóvel onde havia funcionado a fábrica de fiar e tecer algodão, local que o Presidente resolveu transformar em Cadeia Pública, uma vez que a Câmara Municipal, ela mesma funcionando em local precário, não possuía verba suficiente para a empreitada, sendo que quase todo o seu dinheiro era empregado no sustento dos presos. 
A preocupação na época, fica obvio observar que era tão somente em arranjar um lugar para alojar e aprisionar o preso, não se tinha um planejamento de fazer uma estrutura de cadeia, então os porões desses casarões eram muitas vezes adaptados para tais fins, colocando grades e dividindo os quartos, e assim foram fazendo os improvisos, sendo que aquela época já se tinha relatos de falta de espaço e a população carcerária cada vez crescendo.

Enfim já no Brasil República o então Governador Antônio Constantino Nery, em 1905 sinaliza para possíveis melhorias nas situações dos presos, mas para tanto foram desativados os prédios que abrigavam, e estes foram espalhados para vários locais, alguns piores do que a cadeia do qual haviam saído já que havia a necessidade de adequar os presos de acordo com lei vigente visto que houve inúmeras modificações no Código Penal de 1890, o decreto 22.213, de 14.12.1932, aprova como"Cosolidação das Leis Penais" (Ferreira; Valois 2012).

Neste contexto do período áureo da borracha no Estado do Amazonas que foi construída a primeira estrutura de cadeia segundo Ferreira e Valois (2012, p.85):

Afinal fica pronta a obra de Constantino Nery, prisão onde hoje funciona a Cadeia Pública "Desembargador Raimundo Vidal Pessoa", que foi também penitenciária, mas naquele tempo,1907 chamava-se Casa de Detenção de Manaus. Foi instituída pela Lei 524, de 18.10.1906, e inaugurada no dia 19.03.1907, tudo no mesmo governo.

Assim ficou registrado um lugar, um espaço dentro da cidade de Manaus, o Estado ao construir e ao mesmo tempo produziu este espaço, visto que por muito tempo houve a movimentação de diversos agentes produtores do espaço, até a sua desativação em maio de 2017.Antiga Cadeia Pública Desembargador Raimundo Vidal de Pessoa (figura 5)situada na avenida sete de setembro Centro da cidade de Manaus, construída no sec. XX, e o primeiro prédio construído com uma estrutura de presídio, atualmente desativada, foi determinado o tombamento do prédio como Monumento Histórico do Estado do Amazonas. 
Figura 5- Cadeia Pública Desembargador Raimundo Vidal Pessoa (1907)

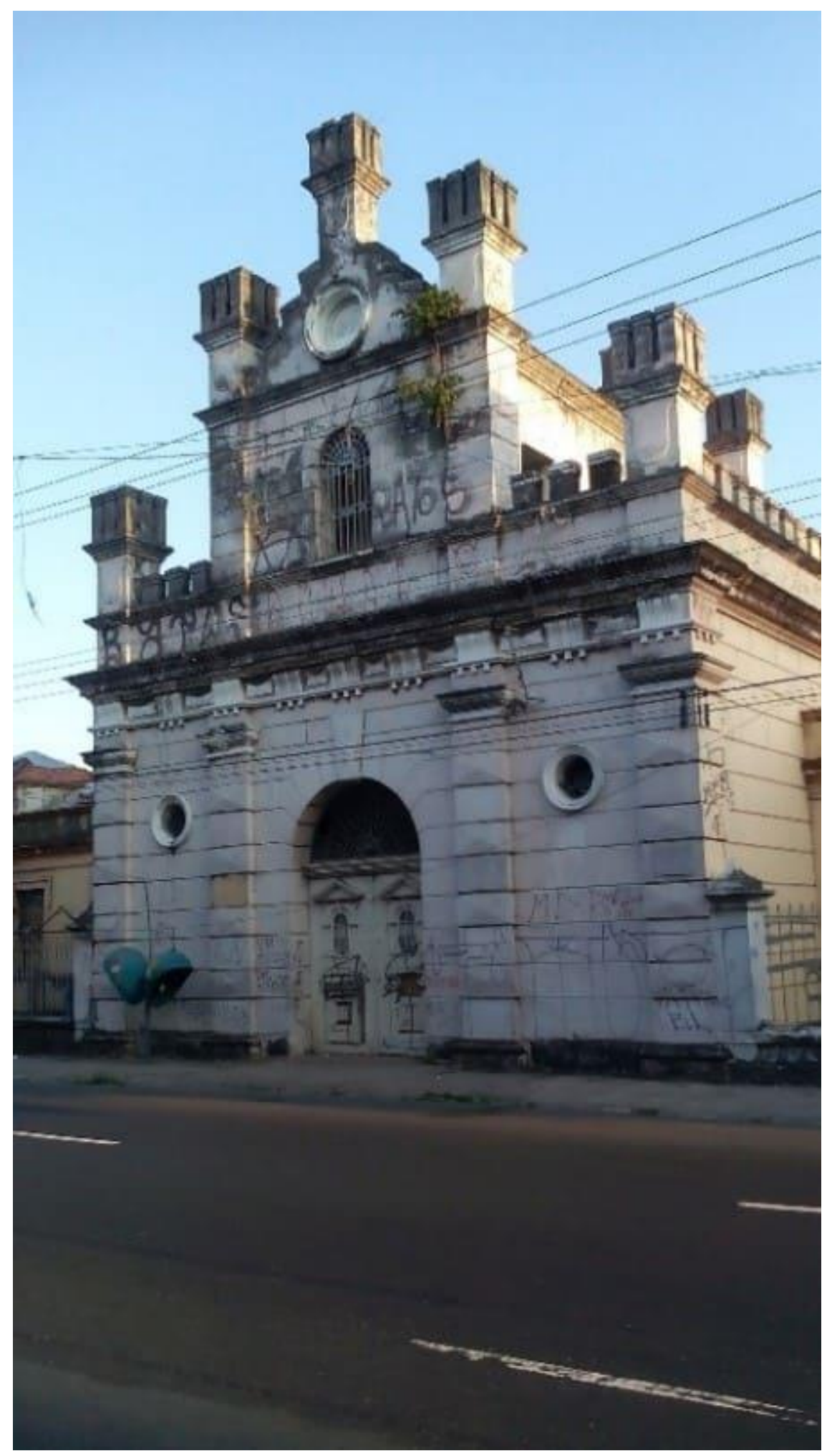

Foto: Sansão Belém, 2017.

RC: 29825

Disponível em: https://www.nucleodoconhecimento.com.br/geografia/producao-do-espaco 


\section{OBRAS REALIZADAS NO PERÍODO DA PESQUISA}

Durante o período da pesquisa, foram encontradas várias obras públicas no ramal, tanto na esfera Federal no caso a construção da guarita da Força Nacional (figura 6) quanto na Estadual a construção do reforço do muro do Complexo Penitenciário Anísio Jobim COMPAJ (figura 7), bem como a construção do poço artesiano (figura 8).

Figura 6- Etapas da Construção da Estrutura do Alojamento e Guarita da Força Nacional
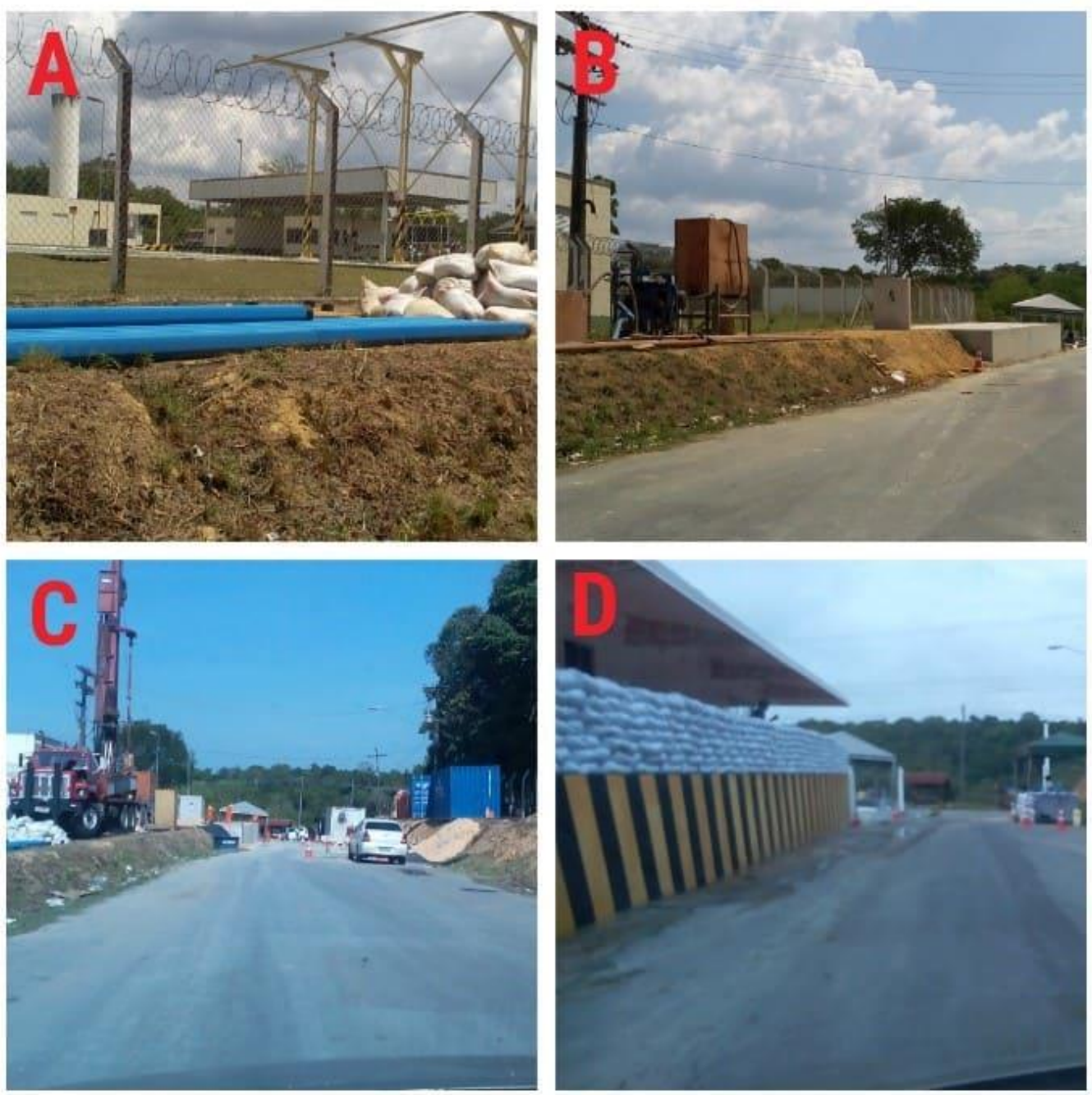

Foto: Sansão Belém, 2017. 
No início do ano de 2017, deu início a construção de uma estrutura para acomodar a Força Nacional, conforme podemos observar na (figura 6) na imagem A, pode ser observado os tubos azuis para a construção do poço artesiano; na imagem $B$ o piso de alvenaria já construído; e na imagem $\mathrm{C}$ a máquina de perfuração de poço artesiano, todo um aparato para construir o alojamento e área administrativa da Força Nacional concluído conforme lado esquerdo da figura $\mathrm{D}$. Esta estrutura fica na entrada do ramal, e é utilizada pela Força Nacional, que presta um serviço de identificação de todos aqueles que entram no ramal, uma vez identificados as pessoas deve informar qual o presidio a ser visitado, e o qual a finalidade, depois de uma avaliação prévia, pode entrar ou não no ramal.

Durante a visita de campo, é visível obras licitadas do Governo do Amazonas sendo realizadas dentro do "ramal dos presídios", como podemos observar essa placa da (figura 7), que trata da construção e reforço do muro do COMPAJ.

Figura 7 - Placa anunciando a construção de reforço do muro Complexo Penitenciário Anísio Jobim -08/09/2018

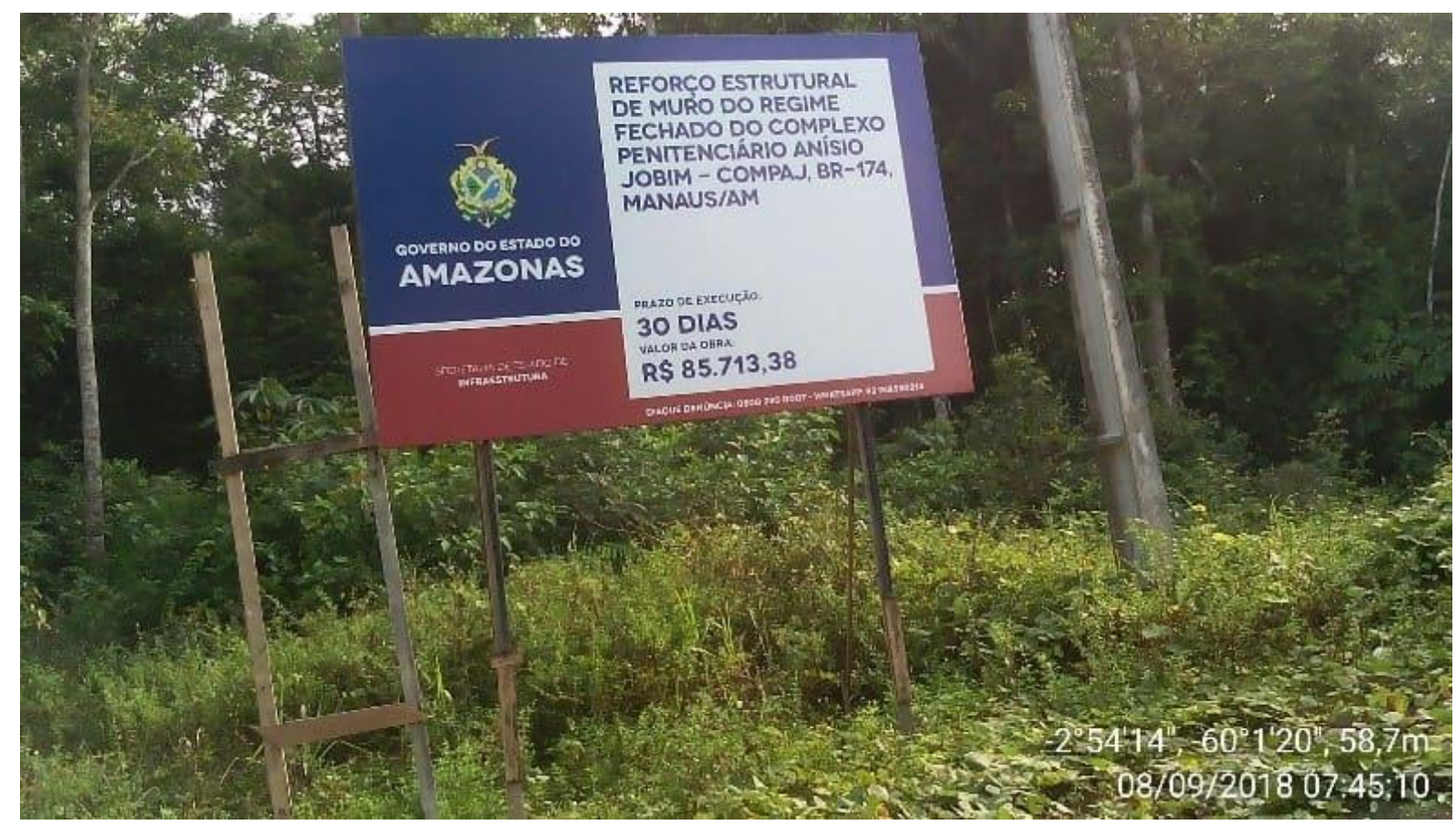

Foto: Sansão Belém, 2017. 
Outra obra já concluída em junho deste ano (2018), foi o poço artesiano (figura 8), mesmo estando desativado o espaço do semiaberto, foi constatado essa obra.

Figura 8- Construção de um poço artesiano dentro do Semi Aberto Compaj

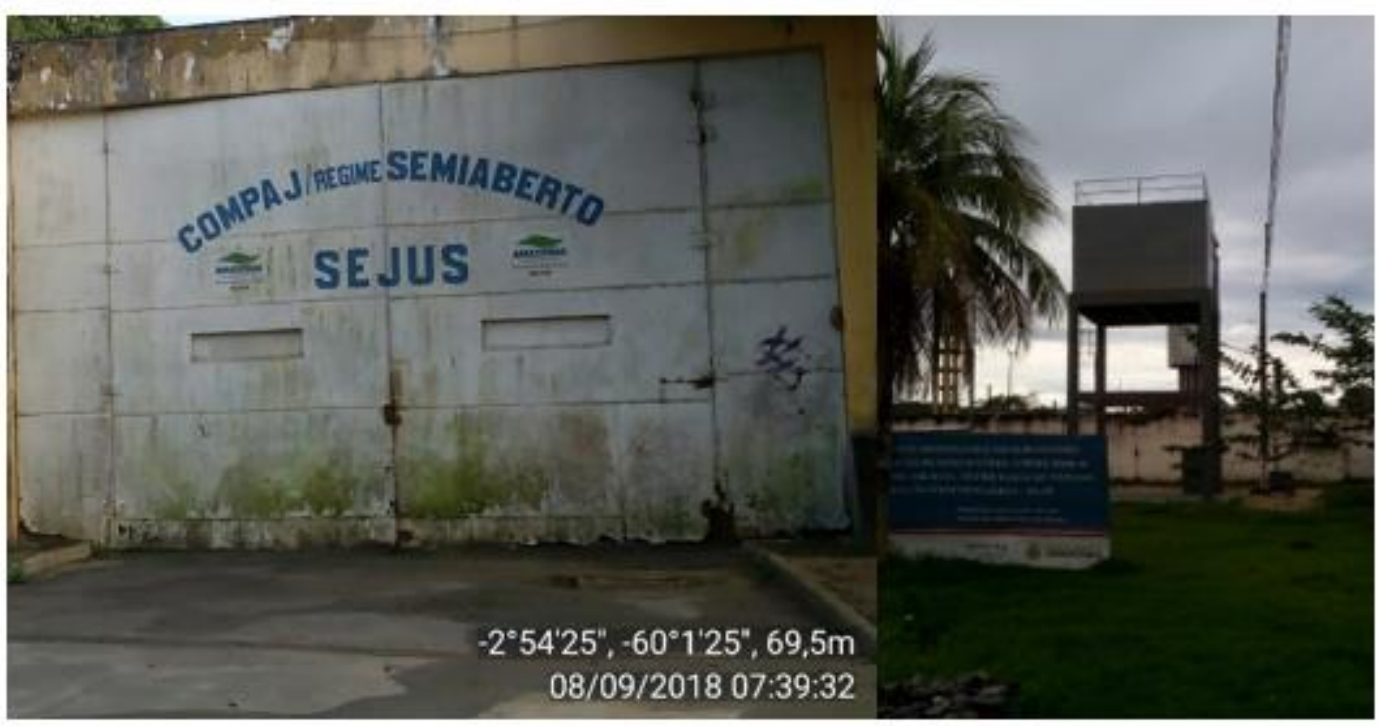

Foto: Sansão Belém, 2018.

Construído dentro do sistema, que por sua vez está desativado temporariamente, possivelmente a evidências que poderá ser construído mais um presidio de regime fechado nesse local.

\section{POPULAÇÃO CARCERÁRIA}

A medida que a cidade cresce, juntos cresce a marginalidade, consequentemente os crimes tendem a aumentar, aumentando a repressão e privando os delinquentes de sua liberdade. É histórico que dentro da estrutura carcerária, a população de presos sempre foi maior que a disponibilidade de vagas. A respeito disso conforme fonte do setor de estatística SEAP (Gráfico 1) foram coletadas informações da população carcerária no Complexo no Km 8 da BR-174 no qual encontram encarcerados os presos dos sete presídios ali existentes, e obtivemos os seguintes dados em 08/2018. 
Gráfico 1- Capacidade, ocupação atual e superlotação dos presídios

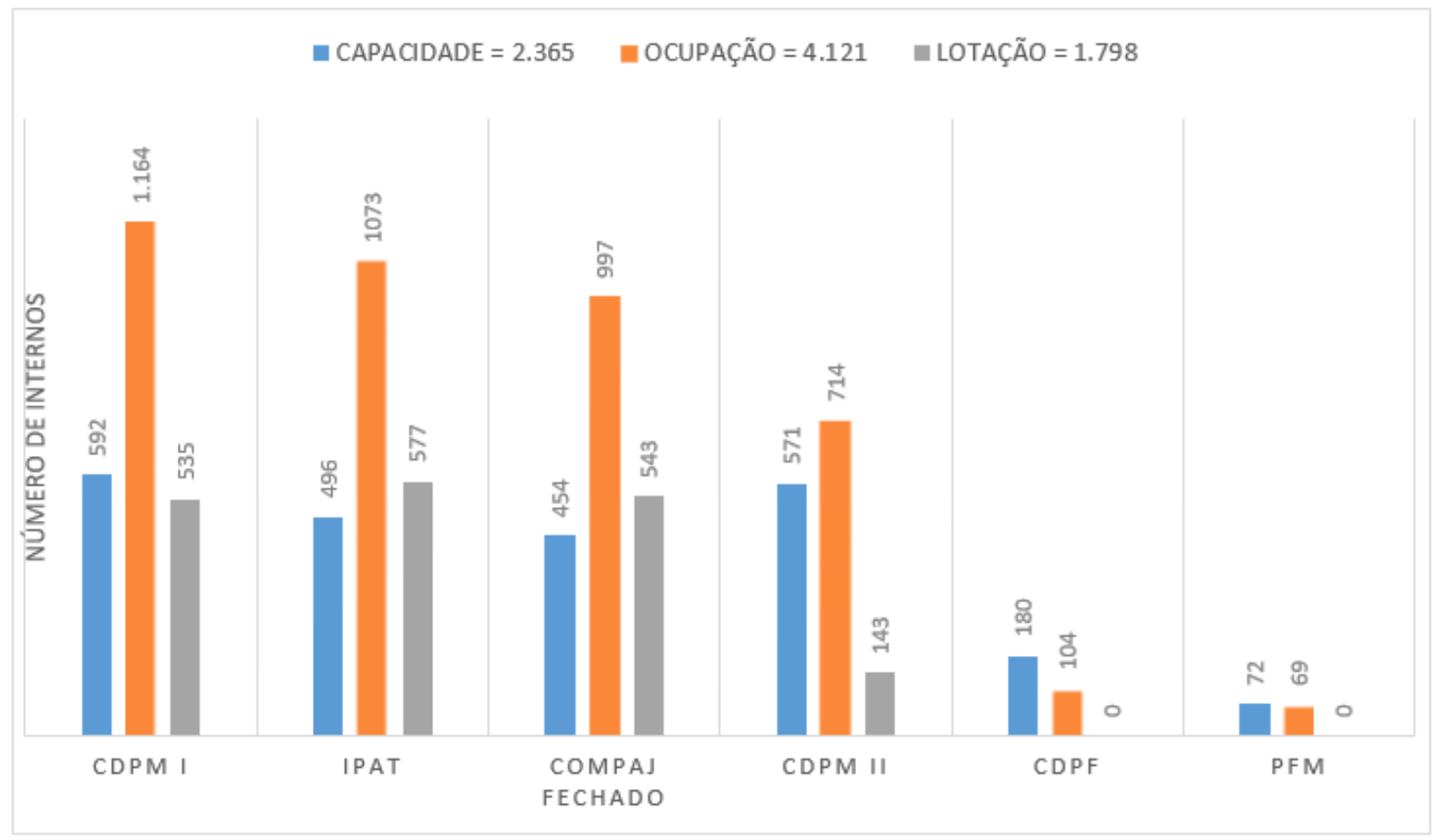

Fonte: Estatística-SEAP, Coleta de dados em 08/2018

Ao analisar o gráfico 1, constatamos a cruel realidade da superlotação dos presídios masculino, porquanto diante dessa análise, fica evidente a falta de políticas públicas voltadas à educação e ao trabalho. Totalizando 4.121 (quatro mil centos e vinte e um) internos na área de pesquisa, sendo que o presidio com o maior número de internos é o CDPM I com 1.164(mil centos e sessenta e quatro) internos, seguido do IPAT com 1.073 (mil e setenta e três) internos, depois o COMPAJ com 997 internos, e CDPM II com 714 internos, todos com sua capacidade de alojamento esgotado. Quanto aos presídios femininos ainda sobram vagas, justificando a construção mais de presídios que atendam o gênero masculino.

\section{IDENTIFICANDO OS AGENTES SOCIAIS PRODUTORES DO} ESPAÇO

A ação do homem em ocupar o espaço pouco a pouco vai tomando forma, assim como a evolução da favela, e a ação dos próprios moradores, que aos poucos e durante um longo período de tempo, vão se adequando quanto as suas moradias e implantando 
atividades econômicas (CORRÊA, 1989). Dessa forma podemos expor o que está ocorrendo à beira do Km 8 na BR-174.Aos poucos as pessoas vão se apropriando do espaço para diversos fins, conforme a (figura 8), os grupos da economia do circuito inferior em 2017 já ocupavam a margem direita no Km 8 da BR-174 com duas barracas de venda de comidas e bebidas.

Figura 8- Comércios na BR-174 Próximo ao ramal dos presídios
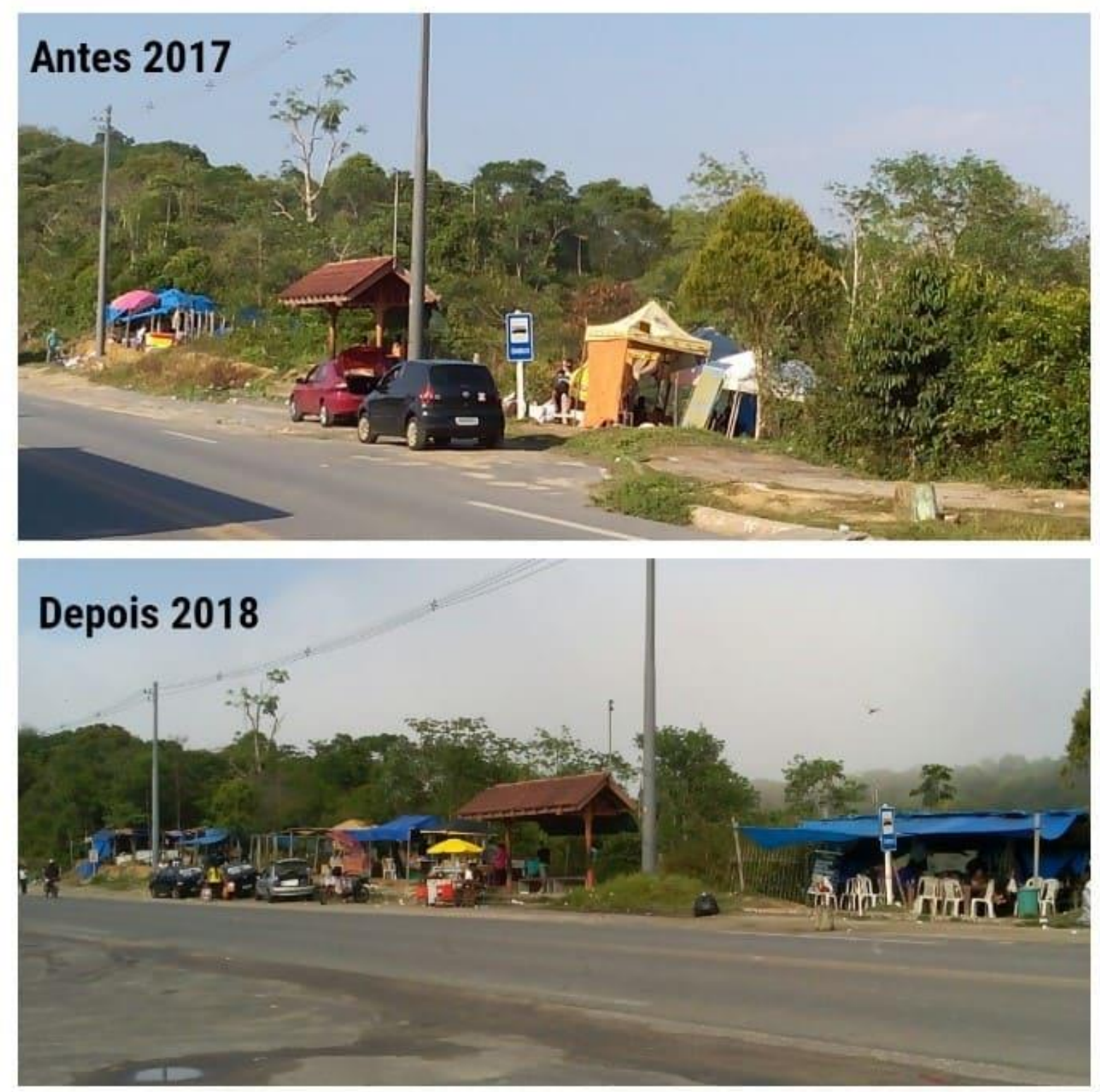

Foto: Sansão Belém, 2018. 
Conforme gráfico 2, dados fornecidos pela SEAP foi coletado o número de visitantes que circulam no Km 8 da BR-174, nos meses de agosto, setembro e outubro/2018, e obtivemos os seguintes resultados:

Total de homens durante os três meses foi de 3.594(três mil quinhentos e noventa e quatro) com uma média por mês de 1.198 (mil cento e noventa e oito), total de mulheres 17.065 (dezessete mil e sessenta e cinco mulheres) com uma média por mês de 5.688(cinco mil seiscentos e oitenta e oito), total de crianças 2.417 (duas mil quatrocentos e dezessete) com uma média de 806 (oitocentos e seis) não tendo estrutura física de acolhimento na entrada do ramal para que essas crianças possam esperar a hora de entrar ao ramal. Dessa forma percebe-se que a maioria de visitantes é do sexo feminino no qual incluem esposas, companheiras, irmãs, mães e avós dos internos.

Gráfico 2- Quantitativo de visitantes nas unidades do Ramal no Km 8 da BR- 174

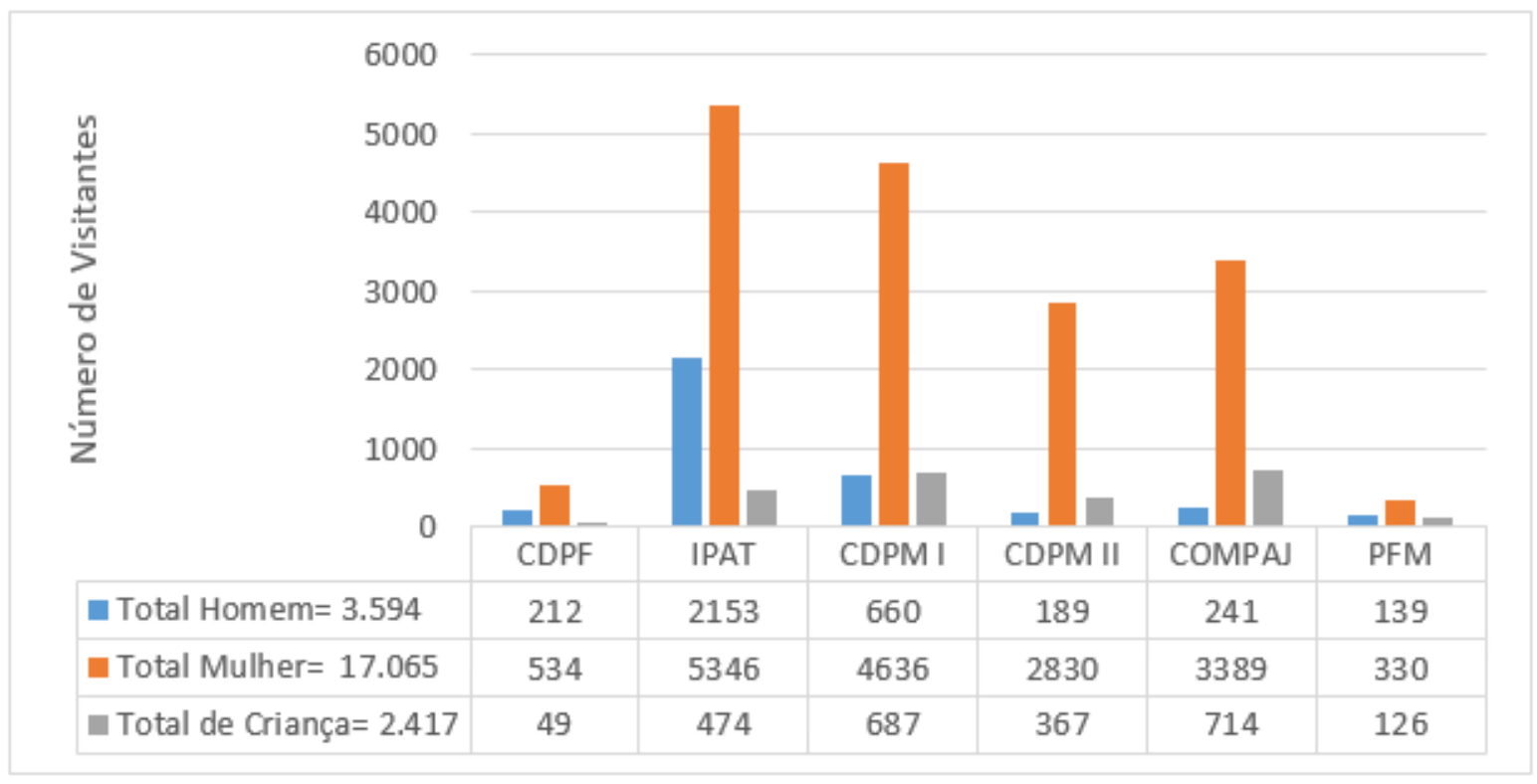

Fonte: SEAP,2018.

Em síntese, por mês calcula-se que circula pelo local da pesquisa em torno de 7.692 (sete mil seiscentos e noventa e duas) pessoas visitantes, não contando com os demais segmentos do moto taxi, Kombi lotação, voluntários da IURD e comerciantes. Tendo como último levantamento da população carcerária um total de 4.121 (quatro 
mil cento e vinte e um) internos, ou seja, o número de visitantes mensalmente é quase próximo do dobro da população de internos.

Com o grande fluxo de pessoas dependendo do transporte coletivo convencional e sem a presença de alguma de estrutura de parada de ônibus, os visitantes dos presidiários chegam até ao início ramal por meio do transporte coletivo convencional da linha 305 (figura 8 A) o mesmo faz parada a beira da BR-174 do lado direito da entrada do ramal dos presídios, este ônibus atende até ao Km 41 da BR-174, para chegar no ramal dos presídios, e com poucas opções de linhas que atendam a essa demanda, aparecem então o moto taxi e as Kombi lotação. Este segmento de forma irregular no ponto de vista legal, fazem esse transporte, dividindo o espaço na entrada do ramal e em frente a fábrica da Quartzolit, o moto taxi, e as Kombi permanecem estacionados no aguardo de um passageiro (figura $8 \mathrm{C}$ ), cada espaço é apropriado e disputado, por diversos grupos que ali se encontram ponto de moto taxi irregular, devidamente marcado com anuncio do percurso (figura 8 D), no Km 8 da BR-174. 


\section{MULTIDISCIPLINARY SCIENTIFIC JOURNAL

Figura 8- Meio de transporte utilizado para chegar no Km 8 da BR-174
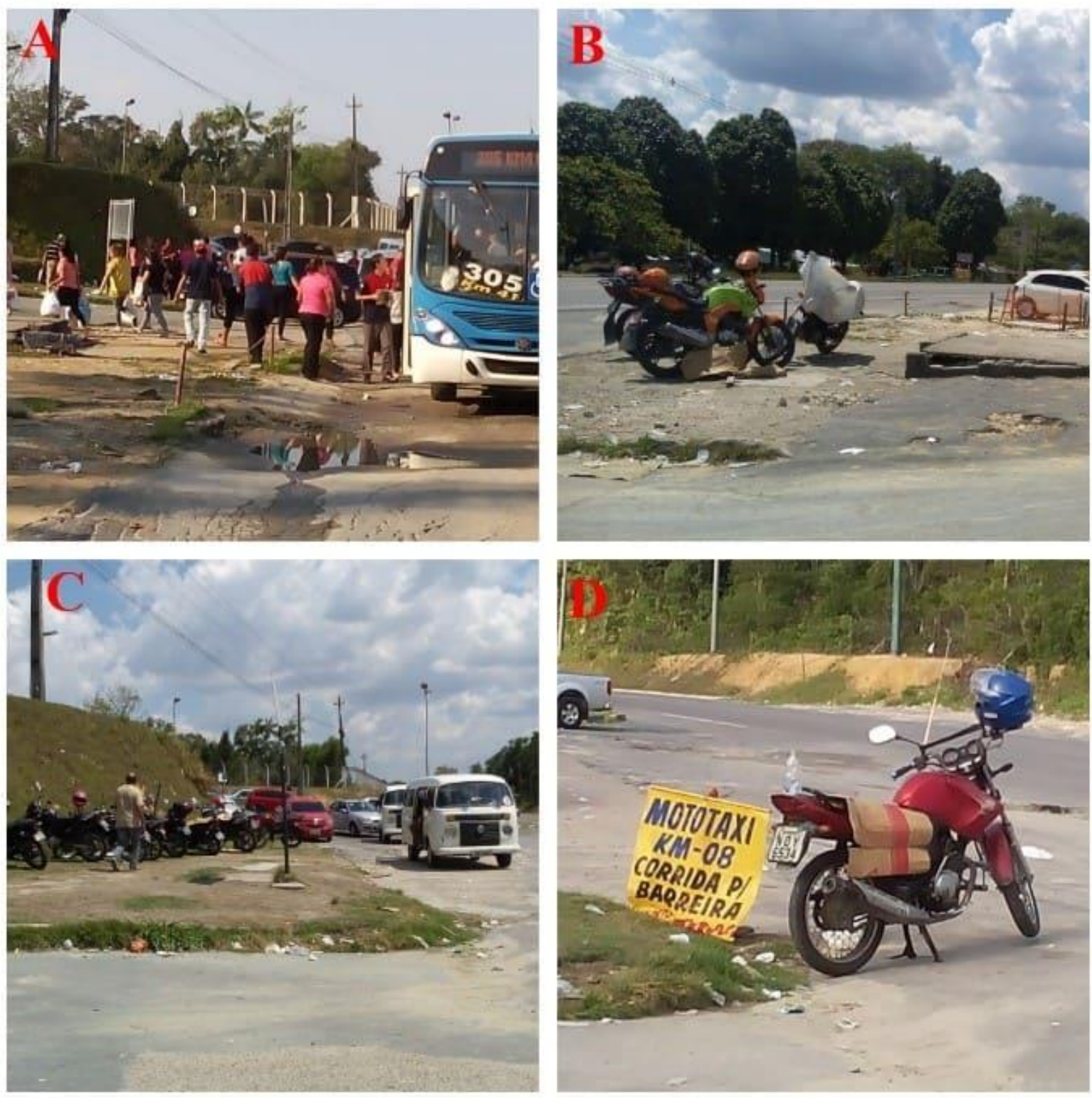

Foto: Sansão Belém, 2018

Sem a presença de fiscalização por parte do poder público nas diversas esferas, esses segmentos se apropriam do espaço para prestação de serviço de transporte dos que precisam para se deslocar até ao ramal. Outro fato vem ocasionando conflitos entre os que trabalham de forma legalizada pelos os órgãos competentes, em uma concorrência desleal na parte do valor cobrado da corrida, informação repassada pelo moto taxi credenciado (figura 8 B). Do lado oposto também na entrada do ramal 
constatou-se a presença de moto taxi devidamente credenciados pela Superintendência Municipal de Transportes Urbanos (SMTU) ocupando o espaço na entrada do ramal dos presídios.

Para prestar um serviço que leve conforto espiritual, um grupo da Igreja Universal do Reino de Deus (IURD) (figura 9), oferece seus serviços aos sábados e domingos na entrada do ramal, eles chegam de ônibus fretado da lgreja, trazem materiais de leitura, jornal, panfletos e distribuem, óleos ungidos, abordam todos que ali estão, tanto visitantes quanto pessoas que aguardam seus visitantes, moto taxis, comerciante e outros mais, confortando com orações e a palavra de Deus.

Figura 9- Membros da Igreja Universal recepcionando os visitantes parentes dos presos

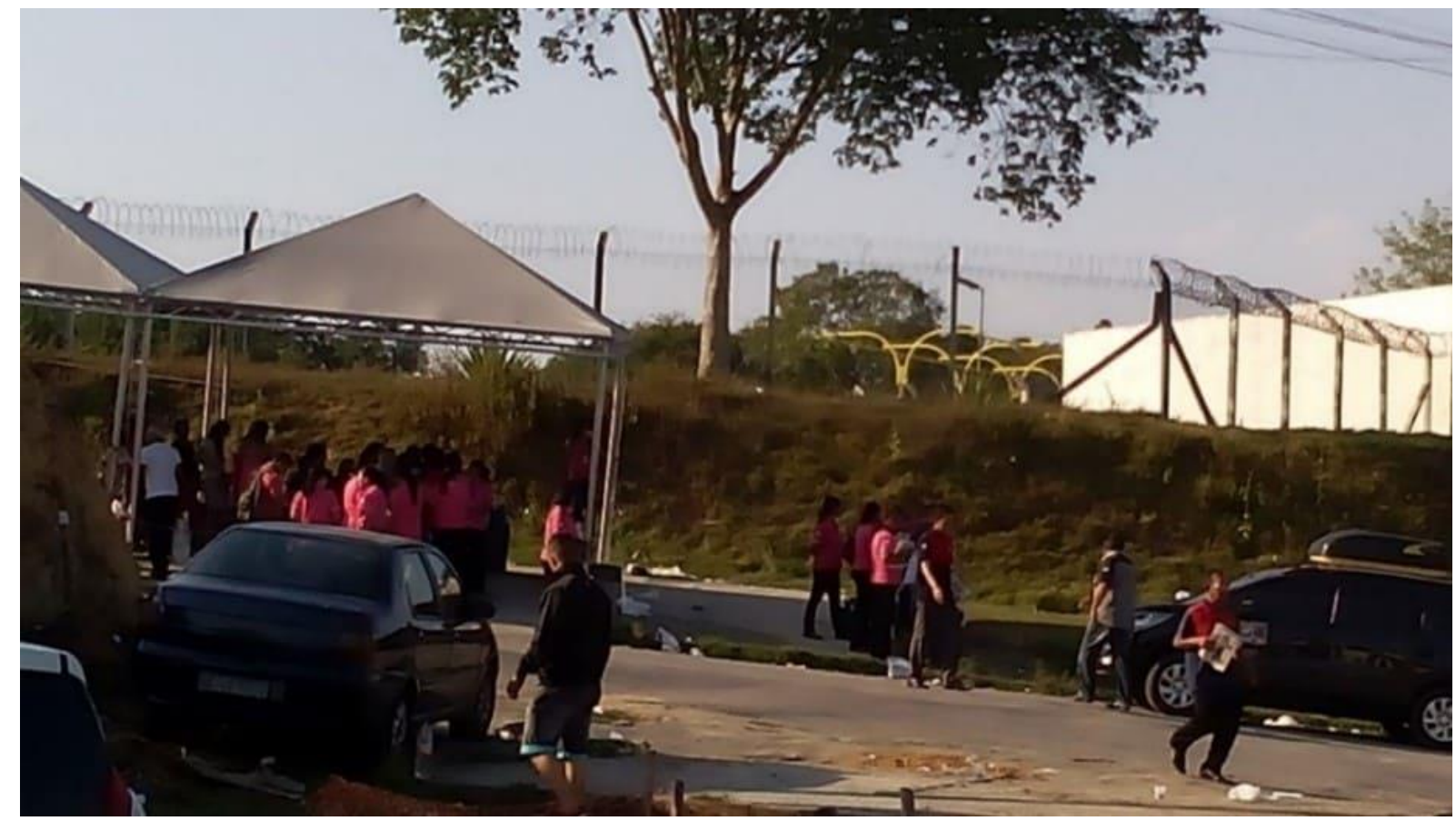

Foto: Sansão Belém, 2018

O visitante dos internos ao chegar na entrada do ramal, encontra nos dias de visita, a presença do Estado via Secretaria de Estado e Administração Penitenciária (SEAP), são colocadas mesas e cadeiras nessa estrutura de lona (figura 10) ao fundo, do lado direito bem próximo ao limite do terreno da Quartzolit. 
Figura 10- Barraca de Lona da SEAP, para identificação dos visitantes

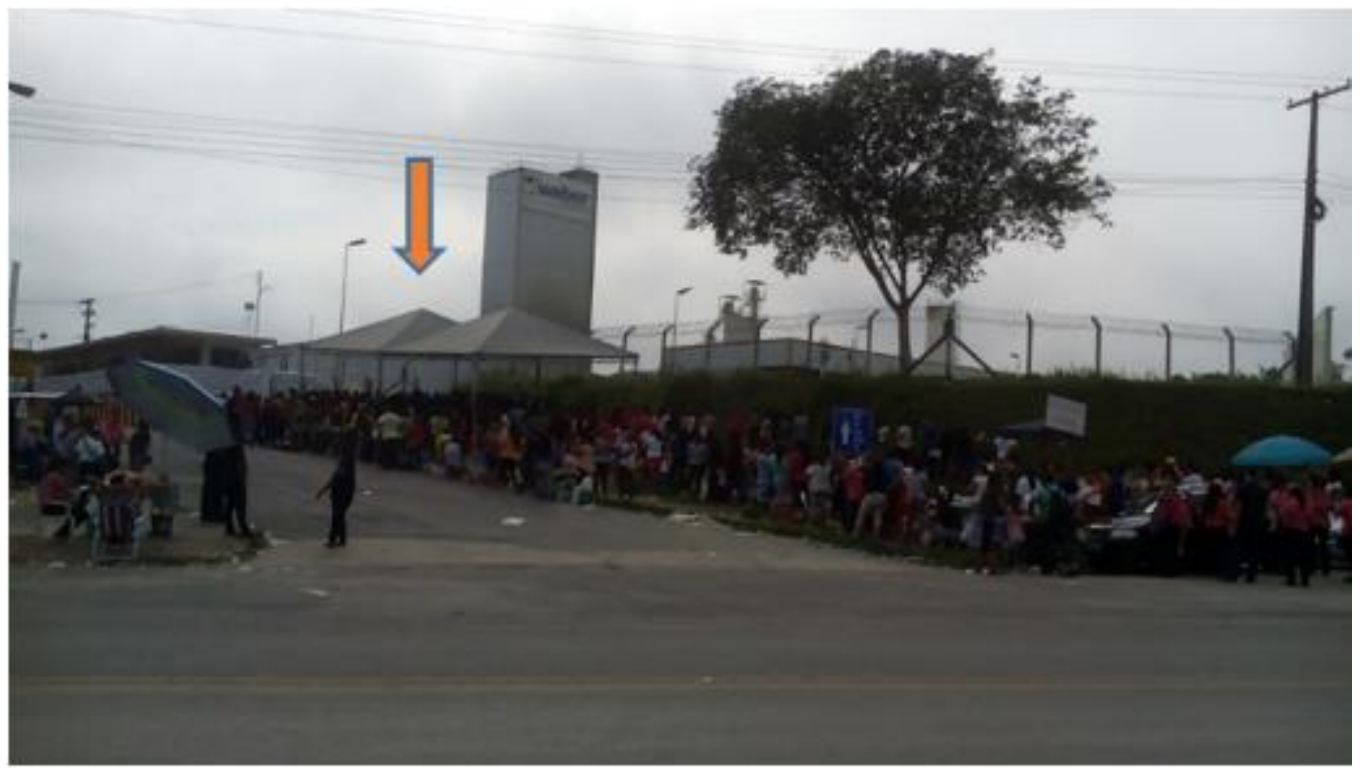

Foto: Sansão Belém, 2017.

São identificados os visitantes conferindo pela lista em qual unidade prisional o mesmo está custodiado, observa-se uma fila longa que contorna a frente da fábrica.

\section{CONSIDERAÇÕES FINAIS}

A partir da construção dos presídios o Estado estimulou o fluxo de pessoas, consequentemente trouxe o comércio, havendo uma valorização das terras no entorno do ramal para esses fins. Porém a investida dos agentes sociais promotores imobiliários na construção de casas, não manifestaram interesse nas proximidades da área pesquisada, possivelmente por ser uma área de presídios.

Desta forma, a análise do objetivo geral da pesquisa ficou inquestionavelmente claro, e evidente, já que a partir da construção dos presídios no ramal, por consequência, outros agentes sociais se estabeleceram no cenário da área de estudo.

Partindo da coleta de dados sobre a população encarcerada dentro da área de estudo, que é de 4.121 (gráfico 2), interno encarcerados até outubro do corrente ano, por conseguinte é de direito do interno ter sua visita familiar, nos dias da semana, que é 
dividido de sexta a domingo, uma vez que com o grande número de interno aprisionados, ficaria muito tumultuado a visita apenas em um dia para todos os presídios, dessa forma a SEAP organizou de forma muito ativa ,a divisão dias de visita em relação aos presídios, na sexta o CDPM II, uma ala, no sábado CDPM II outra ala, ainda no sábado os demais presídios, com opção de escolher ou sábado ou domingo, sendo que quem foi no sábado , já utilizou seu direito de visita, não podendo ir mais no domingo.

É visível a falta de compromisso do Estado, no trato com o ser humano nesse aspecto, uma vez que ao chegar para o pernoite, que já é uma situação degradante ficar dormindo na beira do ramal, sequer tem uma estrutura com banheiros, ou bebedouro. A sociedade paga seus impostos, e esses precisam ser investidos em melhorias no que diz respeito à dignidade humana, um bebedouro, e um sanitário são os itens que mais eles necessitam, já que dentro da estrutura financeira de arrecadação do Estado, pode ser atendido, para dar um pouco mais de respeito ao ser humano. É interessante reiterar a ação humana diante da área de pesquisa, já que havendo visitantes na espera de entrar ao ramal para suas visitas, muitos deles pernoitam, para que no dia seguinte sua entrada seja mais rápida, visto que hão de passar pela longa fila na entrada do ramal, e depois dentro dos presídios a revista pessoal, que fazem parte da segurança de todos. Por conseguinte, as pessoas precisam se acomodar, e se alimentar, logo, na entrada do ramal surge mais um agente social se apropriando do espaço, que são os comerciantes.

Quanto a este segmento, ergue-se da necessidade dos visitantes que contidos pela Força Nacional, e precisam se alimentar, além disso comprar alguns produtos que são vendidos para levar aos internos, haja vista que pelo fato de muitos residirem distantes da BR 174, fica mais cômodo comprar próximo da área, é bom acrescentar ainda que, nos dias de visita de sexta a domingo, foi observado que fica bem dinâmico e atuante todos os segmentos ali presente.

Porém, no questionário aplicado aos comerciantes no Km 8 da BR-174, a principal preocupação apresentada é quanto a um espaço adequado, oficializado pelo poder público, para que possam exercer suas atividades, haja vista que muitos deles 
responderam que "enquanto houver presídios nesta área, ficaremos por tempo indeterminado".

Ainda a respeito dos comerciantes, há entre eles alguns conflitos, por exemplo: um espaço melhor para suas vendas, bem como o aluguel de barracas entre eles mesmo, para exploração do comercio, e almejam formar uma associação de barraqueiros do Km 8 da BR 174.

Quanto a mobilidade dos visitantes até ao ramal, muitos vem de ônibus de linha do transporte coletivo, e em segundo lugar de Kombi lotação, é bom acrescentar ainda que foi observado a presença de moto taxi, tanto na forma legal de trabalho , quanto os que burlam essa prestação de serviço, com isto gerando micro conflitos entre eles, e esse com os que fazem a prestação de serviço em Kombi lotação, uma vez que o moto taxi cobram $R \$ 10,00$ (dez reis) uma corrida do ramal do presídios até ao bairro mais próximo Santa Etelvina, e os que levam as pessoas neste mesmo trajeto em Kombi lotação cobram $R \$ 5,00$ ( cinco reais).

É bom acrescentar que, os serviços de transporte realizados por esses dois segmentos clandestinos, só acontece devido não se ter uma fiscalização na estrada da BR 174, por parte da Policia Rodoviária Federal, há de pensar em que condições de uso estão esses transportes, e a parte documental das pessoas proprietárias e do transporte.

Durante as observações, foi confirmado a presença de um segmento religioso, a lgreja Universal do Reino de Deus (IURD), que se faz presente todos os sábados e domingos, chegam por volta das $5 \mathrm{~h} 30$, de condução própria, trazem sua alimentação e as vezes consumem alimentos vendidos no local, e se retiram por volta das 8 h30.

Segundo o Pastor Valdemir Soares que é responsável pelo grupo, as atividades desenvolvidas por eles são de caráter religioso e social, e mobilizam cerca de 50 voluntários da IURD para levar uma palavra de conforto aos visitantes. Ao amanhecer do dia eles utilizam a área da barraca da SEAP onde fazem as orações juntos com os visitantes que pernoitam no local, em seguida realizam abordagens aos visitantes que 
estão chegando. Segundo o pastor não existe a perspectiva de construção de Igreja Universal do Reino de Deus nas proximidades, haja vista que eles já têm autorização por parte da SEAP, de levar oração dentro de cada unidade prisional e a utilização do espaço da barraca da SEAP. O mesmo destacou o caráter de cunho social, quando no dia das mães, dias das crianças, reuniões aos dependentes químicos e o projeto " A Cura dos Vícios".

Surpreendentemente, após a abordagem do questionário ao pastor, o mesmo informou que: "as respostas dos demais voluntários ali presentes, seriam a mesma dele, e que os mesmos não tinham autorização de falar em nome da IURD". O que na minha opinião compreende-se que sempre temos algo a acrescentar, ou uma ideia, um pensamento diferente e lembrar que todos temos o pleno direito de dar a nossa opinião.

Os resultados da pesquisa foram além das expectativas iniciais, uma vez que elementos humanos e físicos se interagem e estão relacionados direto na produção, no consumo, na apropriação, organização e modificação do espaço e por meio das relações homem natureza.

Assim percebe-se que já está ocorrendo uma ocupação irregular, por parte dos comerciantes locais na área, com perspectiva de fundar uma associação de barraqueiros, por consequência poderá haver uma ocupação irregular de residência, ficando pela própria dinâmica de consumo do espaço o fazer de um novo bairro nas proximidades do ramal.

\section{REFERÊNCIAS}

AMAZONAS. Secretaria De Estado De Administração Penitenciaria- SEAP. 2018. Disponível em: < http://www.seap.am.gov.br/unidades-prisionais-2/>. Acesso em: 01 nov. 2018.

BRASIL. Ministério da Justiça. Código Penal Brasileiro. Brasília: DF, 1940.

CORRÊA, Roberto Lobato. O Espaço Urbano. São Paulo: Ática, 1989. 
FERREIRA, Carlos Lélio Lauria; VALOIS, Luís Carlos. Sistema Penitenciário do Amazonas: história - evolução - contexto atual. 1 ed. Curitiba: Juruá, 2012.

PRADO, Alice Silva do. Educação nas prisões: desafios e possibilidades do ensino praticado nas Unidades Prisionais de Manaus.2015.107 f. Mestrado - Curso de Sociologia da Universidade Federal do Amazonas - UFAM/PPGS.Disponível em:<https://tede.ufam.edu.br/handle/tede/5521>. Acessado em: 04 de dezembro 2018.

SANTOS, M. O espaço dividido: os dois circuitos da economia urbana nos países subdesenvolvidos. $2^{\mathrm{a}}$ ed. São Paulo: EDUSP, 2004.

SPÓSITO, Eliseu Savério. A vida nas cidades. Por que a cidade existe? Morar é preciso. O futuro da cidade. São Paulo: Contexto, 1994.

, Eliseu Savério. Geografia e filosofia: contribuição para o ensino do pensamento geográfico. São Paulo: Editora Unesp, 2004.

Enviado: dezembro, 2018

Aprovado: Maio, 2019 